\title{
PENINGKATAN KUALITAS PROSES PEMBELAJARAN dan KETERAMPILAN BERCERITA MELALUI METODE PAIRED STORYTELLING pada SISWA KELAS IX E MTS NEGERI 2 SRAGEN TAHUN PELAJARAN 2018/2019.
}

\author{
QODARIANA FAUZIAH \\ MTsN 2 Sragen, Jawa Tengah \\ nanajusup@yahoo.co.id
}

\begin{abstract}
ABSTRAK
Penelitian ini adalah penelitian tindakan kelas (PTK) yang bertujuan untuk meningkatkan kualitas proses pembelajaran dan kemampuan bercerita siswa MTs N 2 Sragen dengan metode paired storytelling. Perolehan data bersumber dari informan, dokumen, dan proses pembelajaran. Pengumpulan data melalui analisis dokumen, observasi, wawancara, dan tes yang dianalisis dengan teknik deskriptif komparatif dan analisis kritis. Uji validitas data menggunakan review informan, trianggulasi sumber data, dan trianggulasi metode. Hasil penelitian yaitu kualitas proses pembelajaran mengalami peningkatan yang dari tiap siklusnya. Rata-rata nilai bercerita siswa mengalami peningkatan dari pratindakan sebesar 26,4\% menjadi 52,9\% pada siklus I. Kemudian meningkat menjadi $73 \%$ pada siklus II. Metode paired storytelling dilakukan sebagai berikut: (1) guru meminta siswa menentukan pasangan; (2) guru membacakan cerpen dan meminta siswa untuk menyimak; (3) siswa menentukan urutan alur dan pesan moral dari cerpen; (4) siswa membuat ringkasan cerpen berdasarkan alur cerita; (5) siswa berlatih bercerita bersama pasangannya; (6) siswa tampil menceritakan cerpen dengan pasangannya.
\end{abstract}

Kata Kunci: Kualitas Proses Pembelajaran, Keterampilan Bercerita, Metode Paired Storytelling.

\section{PENDAHULUAN}

Untuk menjalin komunikasi dengan orang lain seperti menyampaikan ide, pikiran, dan keinginan diperlukan perangakat yang penting yaitu bahasa. Tetapi seringkali kita tidak bisa menyampaikan gagasan kepada orang lain dengan baik, melainkan hanya ditujukan kepada diri sendiri seperti berbicara sendiri baik dilisankaan atau dalam hati.

Berbicara adalah aktivitas berbahasa kedua yang dilakukan manusia setelah aktivitas mendengarkan. Dari mendengarkan bunyi-bunyi bahasa itulah manusia kemudian belajar mengucapkan dan akhirnya mampu berbicara (Nurgiyantoro, 2001: 276).

Dalam pembelajaran bahasa Indonesia SMP/MTs kelas IX, terdapat materi Menceritakan Cerpen Secara Lisan yang menuntut siswa untuk bercerita di depan kelas. Tetapi kenyataannya beberapa siswa tidak memiliki keberanian berbicara di 
depan kelas karena tidak percaya diri dan takut. Ada yang berani maju tetapi saat bercerita tidak lancar. Ada pula yang hanya sekedar berdiri di depan kelas tetapi hanya diam membisu. Dengan begitu keterampilan siswa dalam menceritakan cerpen tidak optimal.

Siswa yang bersedia tampil bercerita di depan teman-teman sekelas biasanya adalah siswa yang mempunyai keberanian lebih daripada teman-temannya. Ketidakberanian siswa untuk tampil bercerita disebabkan potensi keterampilan berbicara mereka berbeda-beda. Beberapa siswa sudah mampu menyampaikan perasaan senang atau sedih dengan baik. Namun, siswa yang lain belum dapat menyampaikan gagasannya dengan runtut. Ada pula yang macet saat berbicara karena kehilangan ide saat bercerita. Masalah lain muncul dalam pembelajaran menceritakan cerpen, yaitu guru meminta siswa bercerita satu persatu sehingga menyita waktu pembelajaran. Akibatnya, guru kurang maksimal dalam pembelajaran menceritakan cerpen. Waktu pembelajaran yang hanya 80 menit tiap pertemuan tidak dapat menyelesaikan praktik bercerita seluruh siswa dalam satu kelas. Permasalahan tersebut terjadi pada siswa kelas IX E MTs Negeri 2 Sragen tahun pelajaran 2018/2019. Hasil survei awal pembelajaran Menceritakan Cerpen di kelas IX E menunjukkan bahwa siswa tuntas belajar dengan KKM $\geq 75$ hanya 9 anak atau 26,40\%. Siswa belum tuntas belajar dengan KKM $\geq 75$ sebanyak 25 anak atau 73,60\%.

Berdasarkan pengamatan terhadap siswa, penyebab rendahnya keterampilan Menceritakan Cerpen siswa yaitu: 1) Kurangnya keberanian berbicara siswa, sehingga siswa kurang bersemangat apabila diminta untuk berbicara di depan teman-temannya karena kurangnya motivasi untuk tampil di depan kelas. 2) Siswa kesulitan dalam mengembangkan ide dan mengorganisasikan gagasan secara lancar dan runtut yang disebabkan kurangnya pemahaman siswa terhadap alur cerita dalam cerpen. 3) Metode bercerita secara individu masih diterapkan guru, akibatnya alokasi waktu untuk praktik bercerita kurang sehingga diperlukan sebuah metode yang dapat mengefektifkan alokasi waktu praktik bercerita siswa.

Dari permasalahan yang ditemukan tersebut, peneliti memilih paired storytelling sebagai metode pembelajaran yang memberi kesempatan siswa bercerita secara berpasangan di hadapan teman-temannya. Djamarah dan Zain (2010: 46) menyebut metode sebagai suatu cara yang untuk mencapai tujuan yang telah ditetapkan. Guru menggunakan metode sebagai strategi untuk membuat siswa lebih aktif, semangat, dan inovatif serta mudah memahami pelajaran. Menurut Lie (2007: 70), paired storytelling adalah metode dengan pendekatan interaktif antara siswa, pengajar, dan bahan pelajaran.

Metode paired storytelling merangsang siswa untuk mengembangkan kemampuan berpikir dan berimajinasi. Dengan tampil secara berpasangan dalam pembelajaran menceritakan cerpen, harapannya adalah siswa yang lain termotivasi, tumbuh sikap kerjasama dan kekompakan pada diri siswa. Senada dengan hal tersebut, Isjoni (2010: 80) mengemukakan bahwa metode paired storytelling menuntut siswa untuk bekerja dengan sesama siswa dalam suasana gotong royong dan mempunyai banyak kesempatan untuk mengolah informasi dan meningkatkan komunikasi. 
Dengan meminta siswa bercerita secara berpasangan guru bisa mengefektifkan waktu pembelajaran. Selain itu metode paired storytelling dapat memupuk motivasi dalam diri siswa untuk berani tampil di depan kelas bersama salah seorang temannya.

Penerapan metode paired storytelling diharapkan dapat mengembangkan kemampuan berpikir dan daya imajinasi siswa dalam pembelajaran menceritakan cerpen. Cerita pendek yang telah dibaca dapat disusun kembali dengan kalimat siswa sendiri dan ditampilkan di depan kelas secara berpasangan dengan metode paired storytelling sehingga siswa dapat menciptakan kekompakan dan kerjasama dalam kelompok.

\section{METODE PENELITIAN}

Penelitian ini adalah jenis PTK (Penelitian Tindakan Kelas). Tindakan dilaksanakan dalam 2 siklus dengan tahapan; (1) perencanaan tindakan, (2) pelaksanaan tindakan, (3) observasi dan interpretasi dan (4) analisis dan refleksi. Subjek penelitan ini adalah seluruh siswa kelas IX E MTs Negeri 2 Sragen tahun pelajaran 2018/2019. Jumlah 34 siswa, dengan rincian 18 siswa perempuan dan 16 siswa laki-laki.

Teknik analisis data adalah deskriptif komparatif dan analisis kritis. Teknik deskriptif komparatif yaitu membandingkan hasil antarsiklus, yaitu sebelum penelitian dan hasil akhir setiap siklus. Teknik analisis kritis yaitu mengidentifikasi kelemahan dan kelebihan kinerja siswa dan guru selama proses penerapan tindakan. Teknik analisis ini mempelajari perubahan yang terjadi pada siswa dan suasana di kelas. Hasil analisis tersebut menjadi bahan untuk menyusun rencana memperbaiki tindakan pada siklus berikutnya.

\section{HASIL DAN PEMBAHASAN}

Berdasarkan hasil pengamatan proses pembelajaran menceritakan cerpen pada pratindakan, kualitas proses pembelajaran siswa terlihat sebagai berikut. 1) Bersungguh-sungguh dalam pembelajaran sebanyak 8 siswa. 2) Aktif bertanya maupun menanggapi pertanyaan sebanyak 4 siswa. 3) Antusias dalam bercerita sebanyak 5 siswa. 4) Memperhatikan penjelasan guru sebanyak 10 siswa.

Dapat disimpulkan bahwa kualitas proses pembelajaran bercerita pada survei awal adalah 19,8\%. Berdasarkan hasil bercerita pada survei awal dapat diidentifikasikan sebagai berikut. 1) Siswa mampu bercerita sesuai dengan isi cerpen dengan taraf baik sebanyak 10 siswa, taraf cukup sebanyak 8 siswa, 12 siswa masih dalam taraf sedang, dan sisanya 4 siswa masih dalam taraf kurang. 2) Siswa lancar dalam membawakan cerita dengan taraf sangat baik 1 siswa, 5 siswa dengan taraf baik, 15 siswa dengan taraf cukup, dan 13 sisanya siswa dengan taraf sedang.3) Siswa mampu menghayati cerita dengan taraf baik sebanyak 3 siswa, 10 siswa masih dalam taraf cukup, 19 siswa dalam taraf sedang dan sisanya 2 siswa masih dalam taraf kurang. 4) Siswa mampu mengungkapkan gagasan dengan baik sebanyak 12 siswa, 10 siswa masih dalam taraf cukup, 8 siswa dalam taraf sedang, dan sisanya 4 siswa masih dalam taraf kurang. 5) Siswa mampu memanfaatkan potensi kalimat dengan taraf baik sebanyak 12 siswa, 14 siswa dalam taraf cukup, dan 8 siswa dalam taraf sedang. 
Data di atas menyiratkan bahwa ketuntasan siswa yang dicapai adalah $26,4 \%$ dengan nilai rata-rata 66,9. Hanya 9 siswa yang mampu mencapai batas ketuntasan dengan nilai skor minimal 75. Hasil ini masih rendah karena rata-rata nilai keseluruhan siswa hanya 66,9. Data lengkap disajikan dalam tabel berikut:

Tabel 1. Nilai Survei Awal Pembelajaran Menceritakan Cerpen Siswa Kelas IX E MTs Negeri 2 Sragen.

\begin{tabular}{|c|c|c|}
\hline Rentang Nilai & Frekuensi & Persentase \\
\hline $46-55$ & 6 & $17,6 \%$ \\
\hline $56-65$ & 6 & $17,6 \%$ \\
\hline $66-75$ & 19 & $55,8 \%$ \\
\hline $76-85$ & 3 & $8,8 \%$ \\
\hline $86-95$ & 0 & $0 \%$ \\
\hline Jumlah & 34 & $100 \%$ \\
\hline
\end{tabular}

Gambar 1. Nilai hasil survei awal dalam grafik sebagai berikut.

\section{Nilai Bercerita}

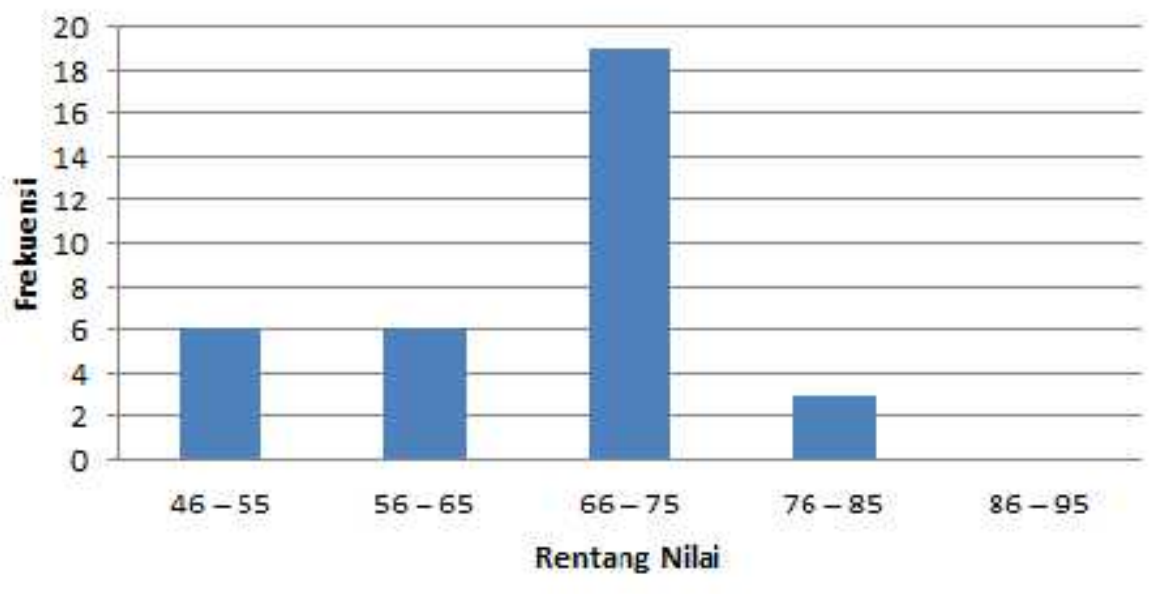

Data tersebut memperlihatkan hasil nilai tes bercerita siswa; hanya 9 siswa yang mencapai KKM dengan nilai 275 . Sedangkan 27 siswa tidak mencapai KKM dengan nilai di bawah 75. Hal ini menggambarkan keterampilan bercerita siswa kelas IX E 
MTs Negeri 2 Sragen masih rendah. Berdasarkan hasil observasi tersebut, dilakukan analisis sebagai berikut. 1) Beberapa kelemahan guru dalam kegiatan pratindakan, sebagai berikut. a) Guru masih dominan dalam menggunakan metode ceramah. b) Guru tidak berkeliling kelas sehingga interaksi dengan siswa kurang. c) Guru belum mampu menciptakan suasana pembelajaran aktif dan menyenangkan. 2) Kelemahan yang bersumber pada siswa, sebagai berikut: a) Siswa merasa jenuh dengan pembelajaran bahasa Indonesia jika hanya mendengarkan guru berceramah, mencatat materi dan mengerjakan tugas. Siswa memerlukan cara pembelajaran yang baru untuk mengatasi kejenuhan. Selama ini siswa merasa kesulitan ketika harus bercerita di depan kelas. b) Siswa merasa kesulitan ketika menuliskan kembali cerpen yang sudah dibacanya dalam bentuk pokok-pokok cerita. Hal ini disebabkan siswa belum memahami pokok-pokok cerita, bagian-bagian penting dari isi cerpen yang harus diceritakan. Hal ini terbukti dari hasil tulisan siswa. Siswa cenderung menuliskan kembali hampir seluruh bagian cerita, tanpa bisa memilih bagian yang penting/pokok dari cerpen sesuai tahapan alurnya sehingga hasil cerita siswa belum maksimal.

Berikutnya diterapkan metode paired storytelling pada tindakan siklus I. Skenario pembelajaran adalah; (1) siswa dipasangkan; (2) siswa membaca cerpen; (3) siswa membuat pokok-pokok cerita dari cerpen yang dibaca; (4) siswa membuat tahapan alur; (5) siswa dan pasangannya melakukan latihan bercerita; dan (6) siswa dan pasangannya tampil bercerita.

Berdasarkan hasil pengamatan terhadap proses belajar mengajar Menceritakan Cerpen siklus I, hasilnya yaitu: 1) Bersungguh-sungguh dalam pembelajaran sebanyak 15 siswa. 2) Aktif bertanya maupun menanggapi pertanyaan sebanyak 17 siswa. 3) Antusias dalam bercerita sebanyak 15 siswa. 4) Memperhatikan penjelasan guru sebanyak 18 siswa.Simpulan kualitas proses pembelajaran bercerita siswa pada siklus I adalah $47,7 \%$.

Berdasarkan hasil pembelajaran menceritakan cerpen pada siklus I, diidentifikasikan sebagai berikut. 1) Siswa mampu bercerita sesuai dengan taraf sangat sesuai sebanyak 10 siswa, taraf sesuai sebanyak 12 siswa, 8 siswa masih dalam taraf cukup, dan sisanya 4 siswa masih dalam taraf sedang. 2) Siswa lancar dalam bercerita dengan taraf sangat lancar sebanyak 2 siswa, 25 siswa dengan taraf lancar, dan 7 siswa dengan taraf cukup. 3) Siswa mampu menghayati cerita dengan taraf baik sebanyak 15 siswa, 18 siswa masih dalam taraf cukup, dan 1 siswa dalam taraf sedang. 4) Siswa mampu mengungkapkan gagasan dengan sangat baik sebanyak 6 siswa, 14 siswa masih dalam taraf baik, 10 siswa dalam taraf cukup, dan sisanya 4 siswa masih dalam taraf sedang. 5) Siswa mampu memanfaatkan potensi kata dengan taraf baik sebanyak 16 siswa, 14 siswa dalam taraf cukup, dan 4 siswa dalam taraf sedang. 6) Siswa mampu memanfaatkan potensi kalimat dengan taraf baik sebanyak 16 siswa, 4 siswa dalam taraf cukup, dan 4 siswa dalam taraf sedang.

Simpulan dari data tersebut yaitu siswa tuntas belajar sebesar 52,9\% dengan nilai rata-rata 72,44. Hal ini cukup baik karena 18 siswa telah mencapai batas tuntas dengan nilai minimal 75 . Tabel berikut menunjukkan data selengkapnya. 
Tabel 2. Nilai Siklus I Pembelajaran Menceritakan Cerpen Siswa Kelas IX E MTs Negeri 2 Sragen

\begin{tabular}{|c|c|c|}
\hline Rentang Nilai & Frekuensi & Persentase \\
\hline $46-55$ & 4 & $11,7 \%$ \\
\hline $56-65$ & 3 & $8,8 \%$ \\
\hline $66-75$ & 14 & $41,1 \%$ \\
\hline $76-85$ & 13 & $38,2 \%$ \\
\hline $86-95$ & 0 & $0 \%$ \\
\hline Jumlah & 34 & $100 \%$ \\
\hline
\end{tabular}

Dalam bentuk grafik sebagai berikut.

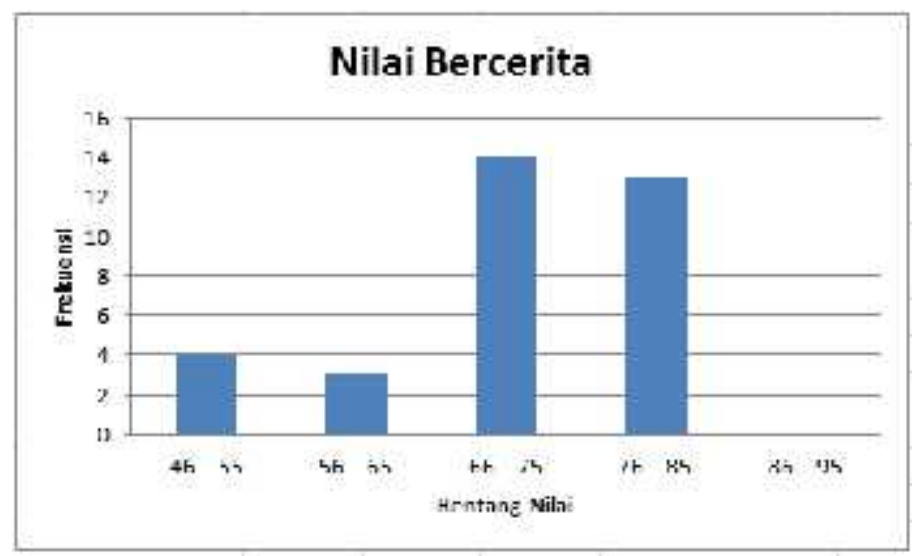

Gambar 2. Histogram Hasil Nilai Keterampilan Menceritakan Cerpen Siklus I

Rangkuman refleksi dari analisis di atas adalah: 1) Siswa cenderung pasif karena guru sering berada di depan dan kurang memantau pekerjaan siswa. Guru harus sering bergerak memonitor seluruh siswa di dalam kelas dan memberi kesempatan siswa menyampaikaan kendala atau kesulitan yaang dialami dalam pembelajaran. Di samping itu, guru bisa mengetahui tingkat pemahaman siswa mengenai materi tersebut. 2) Agar siswa berani mengemukakan gagasan, bertanya, menjawab pertanyaan, dan tampil bercerita secara sukarela, berikan reward dan feedback kepada siswa. Kata-kata pujian dan tambahan nilai kepada pasangan yaang tampil bagus akan memberikan dorongan kepada siswa yang lain untuk berani tampil. 3) Cerpen dipilih yang jelas urutan alurnya. 4) Guru memberi contoh membuat pokok-pokok cerita berdasarkan tahapan alur. 5) Guru memberi contoh cara menilai kelompok. 6) Berikan tambahan waktu berlatih bagi siswa agar penampilan mereka bisa maksimal. 7) Guru memotivasi siswa untuk bersuara keras dan bekerja sama dengan baik dan ketika tampil bercerita pokok-pokok cerita dibawa sebagai bantuan siswa dalam bercerita. 8) Pada pertemuan siklus II peneliti (guru) menjelaskan cara membuat pokok-pokok isi cerpen berdasarkan tahapan alur. Setelah itu dibuka kesempatan untuk bertanya jawab. Selanjutnya siswa bebas memilih pasangan bercerita dan mengerjakan tugas secara 
berpasangan. 9) Selama proses pembelajaran berlangsung, dilaksanakan kegiatan diskusi dan tanya jawab. Hal ini dirasa lebih efektif untuk membangun pemahaman siswa. Pada akhir pertemuan guru menutup pembelajaran dengan memberikan refleksi pada siklus II.

Hasil pengamatan terhadap proses pembelajaran kemampuan bercerita siklus II mengalami peningkatan, hal itu dapat dideskripsikan sebagai berikut. 1) Bersungguhsungguh dalam pembelajaran sebanyak 28 siswa. 2) Aktif bertanya maupun menanggapi pertanyaan sebanyak 23 siswa. 3) Antusias dalam bercerita sebanyak 26 siswa. 4) Memperhatikan penjelasan guru sebanyak 24 siswa. Simpulan data di atas yaitu kualitas proses pembelajaran bercerita pada siklus II adalah 74,2\%.

Berdasarkan hasil bercerita pada siklus II dapat diidentifikasikan sebagai berikut. 1) Siswa mampu bercerita sesuai dengan isi cerpen dengan taraf sangat sesuai sebanyak 10 siswa, taraf baik sebanyak 16 siswa, dan 8 siswa masih dalam taraf cukup. 2) Siswa lancar dalam bercerita dengan taraf sangat baik lancar sebanyak 2 siswa, 27 siswa dengan taraf baik, dan 5 siswa dengan taraf cukup. 3) Siswa mampu menghayati cerita dengan taraf sangat baik sebanyak 2 siswa, taraf baik sebanyak 18 siswa, 13 siswa masih dalam taraf cukup, dan 1 siswa dalam taraf sedang. 3) Siswa mampu mengungkapkan gagasan dengan sangat baik sebanyak 8 siswa, 18 siswa masih dalam taraf baik, dan 6 siswa dalam taraf cukup. 4) Siswa mampu memanfaatkan potensi kalimat dengan taraf sangat baik sebanyak 2 siswa, taraf baik sebanyak 16 siswa, 14 siswa dalam taraf cukup, dan 2 siswa dalam taraf sedang. 5) Siswa mampu menemukan pesan moral dalam cerpen dengan taraf sangat tepat (sangat baik) sebanyak 2 siswa, taraf baik sebanyak 16 siswa, 12 siswa dalam taraf cukup, dan 4 siswa dalam taraf sedang.

Dari identifikasi data di atas, dapat ditarik simpulan bahwa dengan nilai ratarata 74,6 siswa telah berhasil mencapai ketuntasan belajar yaitu sebesar 73,5\%. Dengan begitu terbukti bahwa indikator penelitian telah tercapai pada siklus kedua. Deskripsi hasil dapat dilihat pada tabel berikut.

Tabel 3. Nilai Siklus II Pembelajaran Menceritakan Cerpen Siswa Kelas IX E MTs Negeri 2 Sragen

\begin{tabular}{|c|c|c|}
\hline Rentang Nilai & Frekuensi & Presentase \\
\hline $46-55$ & 0 & $0 \%$ \\
\hline $56-65$ & 7 & $20,5 \%$ \\
\hline $66-75$ & 7 & $20,5 \%$ \\
\hline $76-85$ & 17 & $50 \%$ \\
\hline $86-95$ & 3 & $8,8 \%$ \\
\hline Jumlah & 34 & $100 \%$ \\
\hline
\end{tabular}




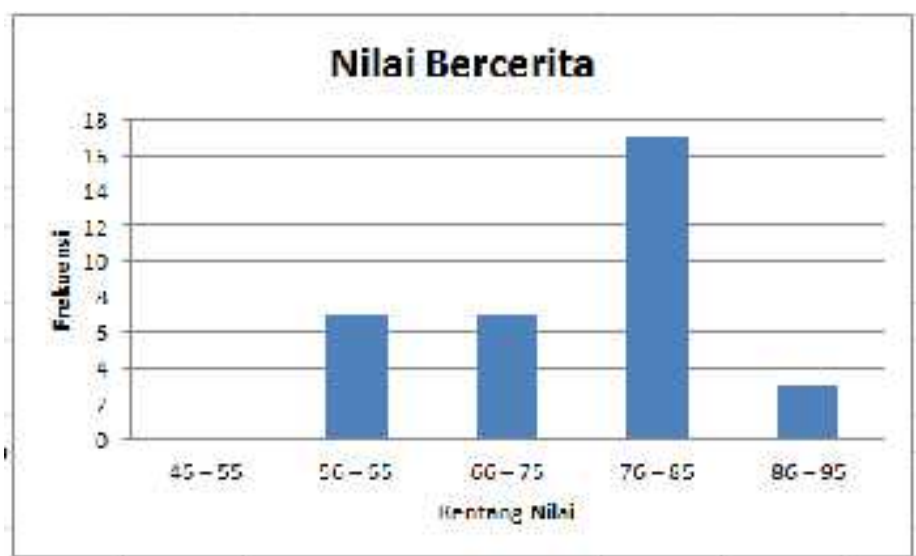

Gambar 3. Histogram Nilai Keterampilan Bercerita Siswa Siklus II

Penerapan metode paired storytelling dapat meningkatkan kualitas pembelajaran Menceritakan Cerpen siswa kelas IX E MTs Negeri 2 Sragen. Terbukti dari tercapainya beberapa indikator yang diterapkan dalam proses pembelajaran tersebut. Dari tiap siklus yang dilaksanakan terjadi peningkatan pada proses pembelajaran yang berimbas pada meningktanya hasil pembelajaran. Setelah hasil dari tiap siklus didesripsikan, selanjutnya dilakukan perbandingan perkembangan antarsiklus untuk mengetahui peningkatan yang dicapai dari satu siklus ke siklus berikutnya. Untuk melihat hasil perkembangannya, perhatikan tabel 4.4 dan gambar 4.12 berikut.

Tabel 4. Perbandingan Hasil Tindakan Antarsiklus

\begin{tabular}{|l|c|c|c|c|}
\hline \multirow{2}{*}{ No } & \multirow{2}{*}{ Aspek } & \multicolumn{3}{|c|}{ Persentase } \\
\cline { 3 - 5 } & & Prasiklus & Siklus I & Siklus II \\
\hline 1 & Proses Pembelajaran & $19,8 \%$ & $47,7 \%$ & $74,2 \%$ \\
\hline 2 & Keterampilan & $26,40 \%$ & $52,9 \%$ & $73,50 \%$ \\
\hline
\end{tabular}

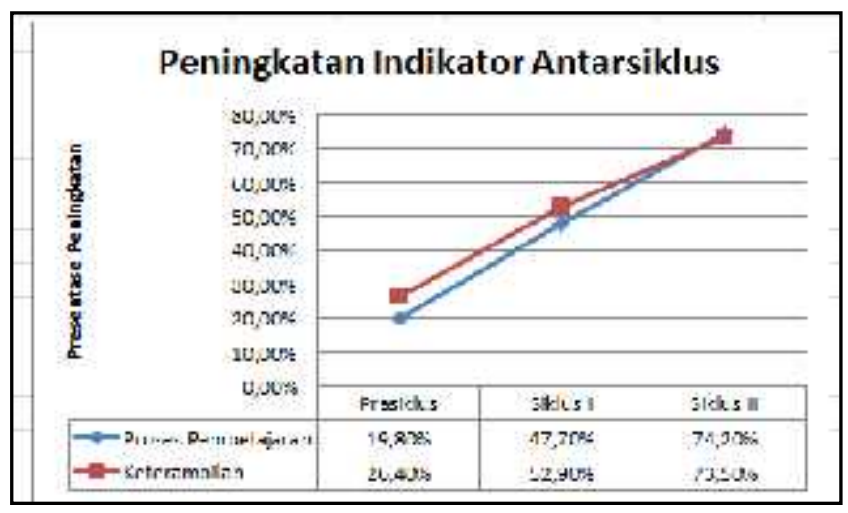

Gambar 4. Peningkatan Indikator Antarsiklus 


\section{KESIMPULAN}

\section{Simpulan}

Penerapan metode paired storytelling dapat meningkatkan kualitas proses pembelajaran pada siswa kelas IX E MTs Negeri 2 Sragen.Hal itu dapat dilihat dari adanya peningkatan kualitas proses pembelajaran siswa dari tahap pratindakan, siklus I dan siklus II. Pada awal sebelum dilakukan tindakan, kualitas proses pembelajaran siswa dalam mengikuti pembelajaran masih rendah, yaitu hanya 19,8\%. Pada siklus I mulai terlihat adanya peningkatan kualitas proses pembelajaran siswa, yaitu menjadi 47,7\%. Pada siklus II kualitas proses pembelajaran siswa sangat baik, dilihat dari peningkatan sebesar $74,2 \%$.

Penerapan metode paired storytelling dapat meningkatkan keterampilan Menceritakan Cerpen pada siswa kelas IX E MTs Negeri 2 Sragen. Peningkatan keterampilan bercerita siswa terlihat dari praktik menceritakan cerpen yang meningkat pada setiap siklusnya. Peningkatan persentase ketuntasan hasil belajar siswa, yaitu dari $26,40 \%$ pada tahap pratindakan menjadi $52,90 \%$ pada siklus I. Meningkat lagi menjadi $73,50 \%$ Pada siklus II. Peningkatan nilai rata-rata kelas tiap siklua adalah; tahap pratindakan 66,1 , siklus I naik menjadi 72,4 dan siklus II meningkat menjadi 74,7.

\section{Saran}

1) sebaiknya guru menggunakan metode paired storytelling dalam pembelajaran keterampilan bercerita karena terbukti meningkatkan kualitas proses pembelajaran dan keterampilan bercerita. 2) Sebaiknya peneliti lain dapat melanjutkan penelitan ini pada objek lain.

\section{DAFTAR PUSTAKA}

Arikunto, Suharsimi, Suhardjono, Supardi. 2007. Penelitian Tindakan Kelas. Jakarta: Bumi Aksara.

Bachri, S. Bachtiar. 2005. Pengembangan Kegiatan Bercerita, Teknik dan Prosedurnya. Jakarta: Depdiknas.

. 1994. "Paired Storytelling: An Integrated Approach For English As A Foreign Language Students In I ndonesia". Dissertation. Faculty Of Doctor Of Education. Baylor University. Diperoleh 8 Februari 2016, dari http://eresources.perpusnas.go.id/.

Djamarah, Syaiful Bahri dan Aswan Zain. 2010. Strategi Belajar Mengajar. Jakarta: Rineka Cipta.

Nurgiyantoro, Burhan. 2001 (ed. Ke-3). Penilaian dalam Pengajaran Bahasa dan Sastra. Yogyakarta: BPFE.

Sumarwati dan Slamet Mulyono. 2011. Model, Media, dan Evaluasi dalam Pembelajaran Bahasa Indonesia. Modul PLPG. Surakarta: Universitas Sebelas Maret.

Suwandi, Sarwiji. 2011. Penelitian Tindakan Kelas dan Penulisan Karya Ilmiah. Surakarta: Yuma Pustaka. 